\title{
A Sediment Detection Analysis with Multi Sensor Satellites: Caspian Sea and Persian Gulf case studies
}

\author{
M. Majidi Nezhad ${ }^{1}$, D. Groppi ${ }^{1}$, P. Marzialetti ${ }^{2}$, G. Laneve ${ }^{2}$ \\ ${ }^{1}$ Department of Astronautics, Electrical and Energy Engineering (DIAEE), Sapienza University of Rome \\ Rome, Italy \\ meysam.majidinezhad@uniroma1.it-daniele.groppi@uniroma1.it \\ ${ }^{2}$ School of Aerospace Engineering, Sapienza University of Rome \\ Rome, Italy \\ pablo.marzialetti@uniroma1.it-giovanni.laneve@uniroma1.it
}

\begin{abstract}
Nowadays the use of multi sensor satellite data for developing and mapping the distribution of suspended particulates in coastal area, sea and ocean waters is increasing in many sciences including environmental and marine studies. This study focuses on using remote sensing satellite images to monitor and detect Suspended Sediment (SS) event of coastal areas. MODIS (or Moderate Resolution Imaging Spectroradiometer)-Terra satellite sensor data (9 Jun 2018) of the east coast of Caspian Sea (between Turkmenistan and Iran) and the north-western of Persian Gulf (between Iran, Iraq, Kuwait) were used. For detecting Suspended Sediments Event (SSE) low-spatial resolution (250-1000m) sea and ocean color satellites data can be used. Multi-spectral sensor satellite images over the Caspian Sea and Persian Gulf have been analyzed to detect, to characterize and to classify suspended sediments in this part. Moreover, this paper discusses suspended sediments detection by using multi sensor satellite images and spectrum matching has been used to identify the sediments areas. In particular through the spectrum matching the direct identification of specific materials has been carried out via the extraction of the specific spectral features. ENVI software has been used to carry out the analysis. Using this software, the suspended sediments close to the coastal area have been successfully detected.
\end{abstract}

Keywords: Sea Pollution, Multi-spectral sensor satellite, Suspended Sediments, MODIS-Terra.

\section{Introduction}

Monitoring and analysis of coastal and marine areas is of utmost importance. Several analysis methods have been proposed as environment sensitivity [1], risk assessment [2], the use of GIS [3] and others. In this context, the use of multi sensor satellite data to detect, identify and record environmental pollution data on sea water has significantly increased in the last decade. The Coastal Zone Color Scanner (CZCS) was the first satellite-borne sensor with radiometric sensitivity designed and developed for use in monitoring marine environment science [4]. Coastal sea and ocean waters are often characterized by a high value of variability in the concentration of Suspended Particulate Matter (SPM) [5]. For detecting suspended sediments events in coastal sea and ocean waters, researchers can use low or high-spatial resolution satellites data such as those provide by: SeaWiFs [4], MERIS [6], GOCI image [7], Landsat [8], Sentinel-3 [9], MODIS [10]-Aqua and Terra [11]. In particular, multispectral sensors like MODIS offer a high number of spectral bands to detect, identify, classify, describe and guarantee daily image frequency [12].

MODIS-Terra and Aqua satellite has 36 bands between range 0.405 and $14.385 \mu \mathrm{m}$ and views the entire surface of the earth every 1-2 days; moreover, these satellite data have 3 level of spatial resolutions $250 \mathrm{~m}, 500 \mathrm{~m}$, and 1,000m and can be used by researchers in various sciences for studying global dynamics and processes occurring on the land, sea, ocean and lower atmosphere.

Suspended sediments not only play an important role on the ecosystem [13] and the environment [14], on water quality [15], nutrient circulation [15], fish and shellfish populations [17], but also in the analysis of crust evolution [18], climate changes [19] and biogeochemical cycling of pollutants [20], and oil spill dispersion [21-23], impact [24] and risk [25]-[26]. Many factors can affect the suspended sediment distribution in the coastal sea and ocean waters: e.g. type of sediments [15], water temperature, salinity and density [27]. The significant purpose of such remote sensing satellite studies is to better understand the carbon cycle and the role of global, interactive earth system models able to predict global change. Therefore 
the monitoring sea and ocean marine environment science [27] becomes interested in remote sensing analysis [29] of the coastal zone sea and ocean waters [30]. Many studies on suspended sediments detection and analysis have been conducted in most of the main seas and oceans with different satellites and methods: Long [31], Mobasheri [32], Madrinan [32], Baeye [34], Guzmán [35], Fettweis [36], Brewin [37], Zhang [39], Wang [40] and about sediment in Caspian sea [41].

ENVI software can be used not only for the visualization and analysis of all types of imagery but it also includes specific packages such as spectral profile tools, geometric correction tool [42], GIS [43], powerful 3D, pixel exploration [44]. In this study ENVI 4.8 software has been used for detection, analysis and classification.

In this framework, this work aims at applying and implementing a developed methodology to detect and analyse two suspended sediments events using multi-spectral sensor satellite images in east coast of Caspian Sea and north-western of Persian Gulf.

\section{Case study area}

The Caspian Sea (Fig 1), considered as the largest lake in the world, is located between the $36^{\circ} 60$ south and $47^{\circ} 06$ north and includes Iran, Azerbaijan, Turkmenistan, Russia and Kazakhstan. This water body covers a surface area of around $380,000 \mathrm{Km}^{2}$ and has a volume of about $78,000 \mathrm{Km}^{3}$. The basement surface of the South Caspian depression lies at depth of 20-25 km [45].

The Persian Gulf (Fig 1) is located between $24^{\circ}$ and $30^{\circ} 30^{\prime} \mathrm{N}$ latitude and from $48^{\circ}$ to $56^{\circ} 25^{\prime}$ E longitude and considered an extension of the Oman Sea. The Persian Gulf borders include: Iran, Saudi Arabia, Kuwait, Qatar, Emirates, Bahrain, Oman and Iraq. The average depth in this Gulf around $35 \mathrm{~m}$ for Arabian coast and the deepest for the Iranian coast are about $100 \mathrm{~m} \mathrm{[46],} \mathrm{and} \mathrm{length} \mathrm{is} \mathrm{about} 865 \mathrm{~km}$ and $370 \mathrm{~km}$ wide [47].

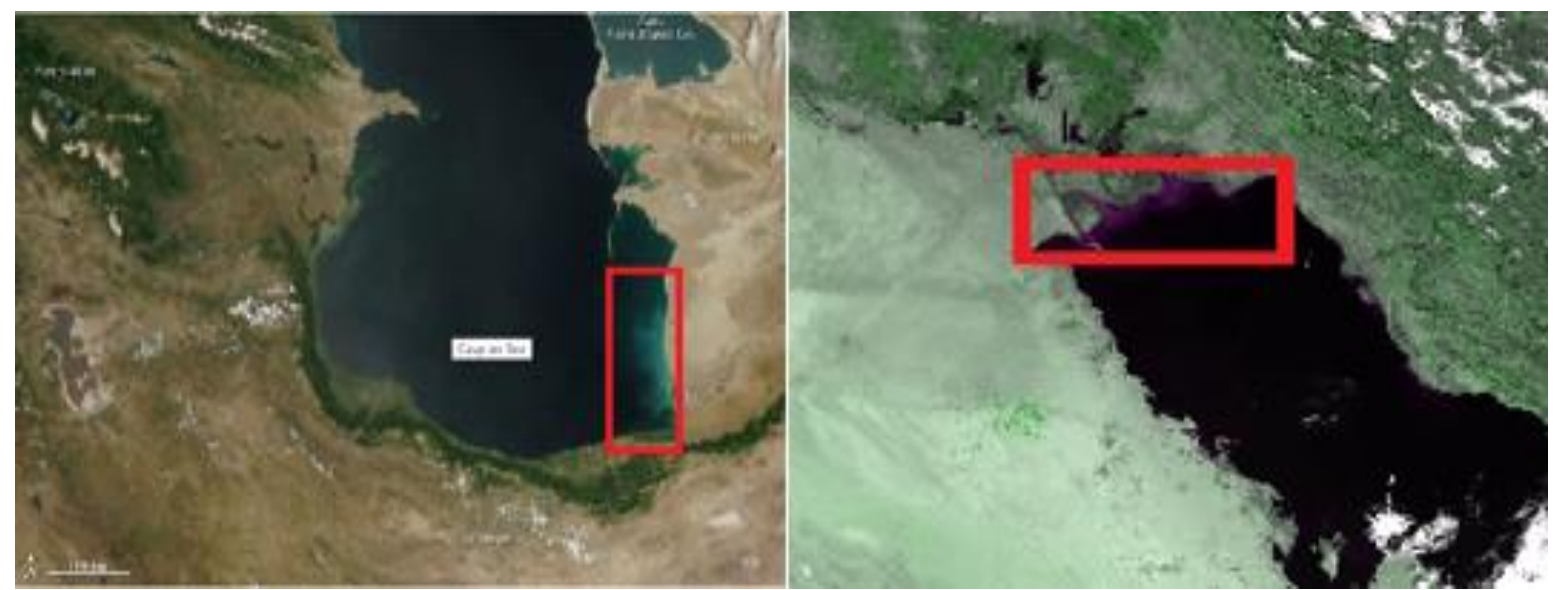

Fig. 1: Left, The Caspian Sea study area (red square). Right, The Persian Gulf study area (red square), Downloaded by https://earthobservatory.nasa.gov.

\section{Method}

The use of multi sensor satellite to develop mapping suspended sediment surveillance and recording is well established for a variety of sea and ocean waters. A general method is to monitor multi sensor satellite reflectance measured in the band 1 of the obvious spectrum to analyse the main parameters of water suspended sediment. MODIS -Terra, band 1 has a great deal of benefits for study by researchers about suspended sediment because band 1 coverage in the red spectral region (620$670 \mathrm{~nm}$ ) at a high sensitivity, and near daily coverage. The main reason for chosen band 2: water radiance significantly lower than land radiance in stronger absorption of water, motion for coastal sea and ocean waters studies. This study develops a methodology based on the relationship between MODIS-Terra satellite band 1, 2 data and Suspended Sediment obtained from two coastal area in Caspian Sea and Persian Gulf.

MODIS satellite or Moderate-Resolution Image Spectroradiometer operates in 36 bands: 20 within 0.4-3.0 $\mu \mathrm{m}$ and 16 within $3-14.5 \mu \mathrm{m} .2$ bands have $250 \mathrm{~m}$ resolution, 5 bands have $500 \mathrm{~m}$ resolution, and 29 bands have $1000 \mathrm{~m}$ resolution. MODIS datasets is free and can be download from the MODIS website. MODIS level 1B calibrated radiance $250 \mathrm{~m}$, band 1 (Range between 620-670nm) and band 2 (Range between 841-876nm) has been used for this paper. MODIS data at the first 
need to be georeferenced and corrected [48]. In this study MODIS has been used because of its revisit frequency and spatial resolution, that were widely applied in deep sea and ocean coastal area waters [49]. Regions of interest (ROIs) tool has been used for classification, masking, and operations. In this study the following procedure has been applied step by step: ROI tool has been used to identify different areas of the image characterized by many water conditions to extract spectral characteristics.

FLAASH tool [50] has been developed by SSI (or Spectral Sciences, Inc.), the leader of the research on atmospheric correction algorithm, and the sponsorship of the AFRL (or United States Air Force Research Laboratory). FLAASH tool [51] is a first-principles atmospheric correction that able to corrects wavelengths in the visible through near and shortwave infrared regions. The input images for FLAASH tool should be a radiometrically calibrated radiance image. Numerous researchers have made atmospheric correction studies working different images and methods of atmospheric correction, such as: Adler-Golden [51], Guo [52].

\section{Results}

Suspended sediments in east coast of Caspian Sea and north-western of Persian Gulf are showed in Fig 2. Huge tendrils of sediment were found in the MODIS-Terra image collected in 2018, January 9th. The empirical algorithm described above has been applied to numerous MODIS-Terra images. Sample result from the data acquired over east coast of Caspian Sea and Persian Gulf, are described. Fig 2 shows large areas of sediments in the east of Caspian Sea and north-western of Persian Gulf part of the images are also well identified. Caspian Sea, sediments areas length $200 \mathrm{~km}$ north to south and up to $120 \mathrm{~km}$ west from the shore. Persian Gulf, The mixing two factor wind and deserts leads in this area to dust storm. These Purple hues in satellite image could result from phytoplankton marine. Furthermore, the same winds that stirred up the dust also most important factor for the ocean wave. These waves cause disturbed the sea and ocean waters surface and suspended sediments near the surface. Fig 3, showed MODIS-Terra, band 1 (range between 620-670nm) and band 2 (range between 841-876nm) images.

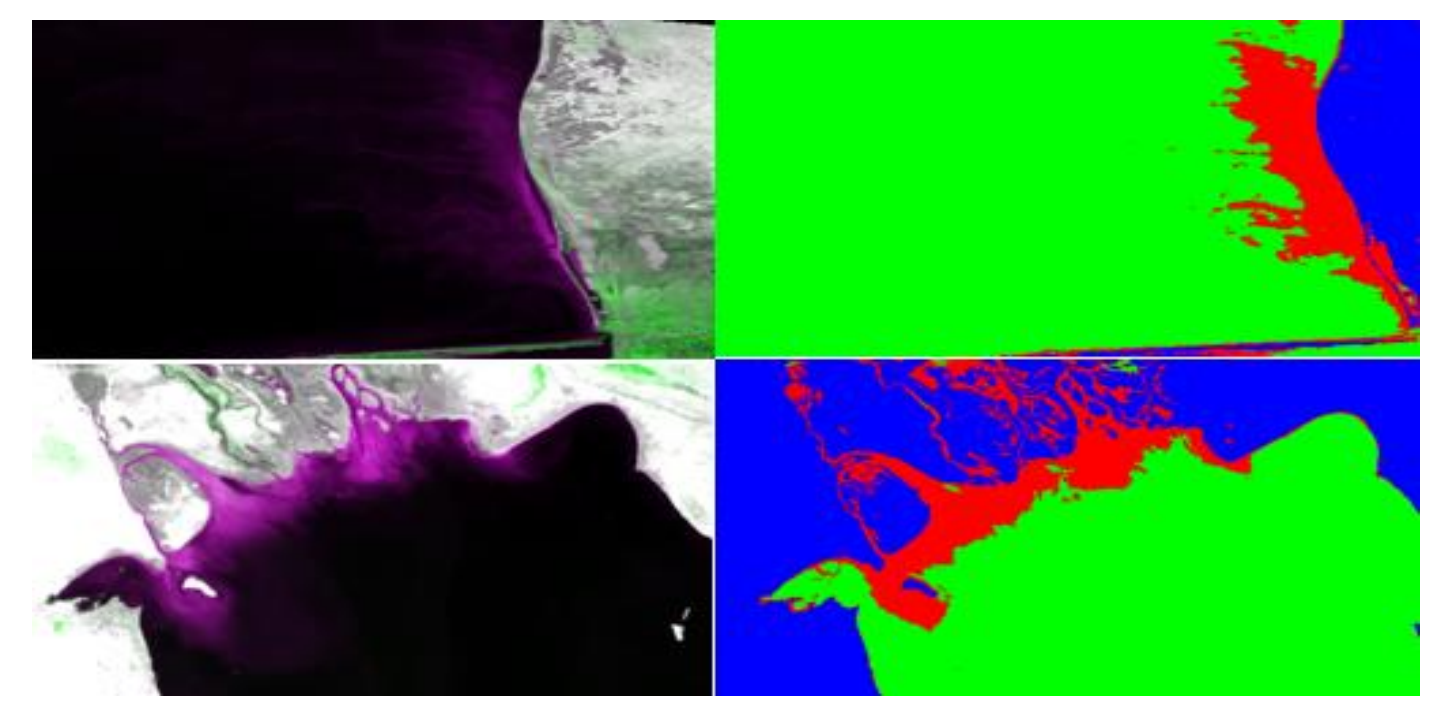

Fig. 2: MODIS-Terra images processed with ENVI software and then classified by ROI (or Region of Interest) tool for January 9. 2018 in Caspian Sea (up) and Persian Gulf (down). Images (up-left) and (down-left): purple area show suspended sediments in coastal areas and surface winds help the water sea and sediments for mix with together, that import a light purple colour. Images (up-right) and (down-right): colour blue showed the land area, red is suspended sediments and green for clean water. 


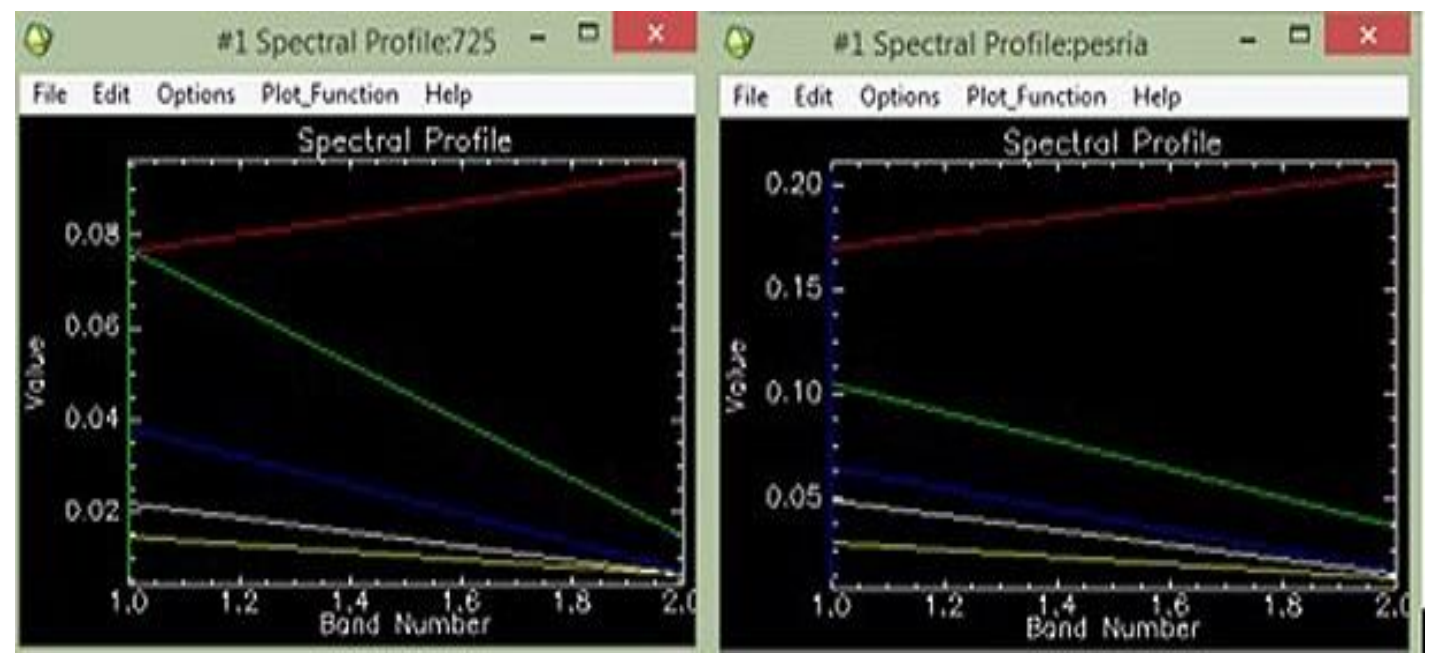

Fig. 3: Spectrum Matching has been used to identify the sediments area, by means of the spectrum matching the direct identification of specific materials has been developed via the extraction of the specific spectral features. Red-land, green-near the coastal (Sediments), blue- far the coastal (sediments mixed with sea clean water), yellow- clean water. (Fig 4 left) showed Caspian Sea spectral profile and (Fig 4 right) showed Persian Gulf spectral profile.
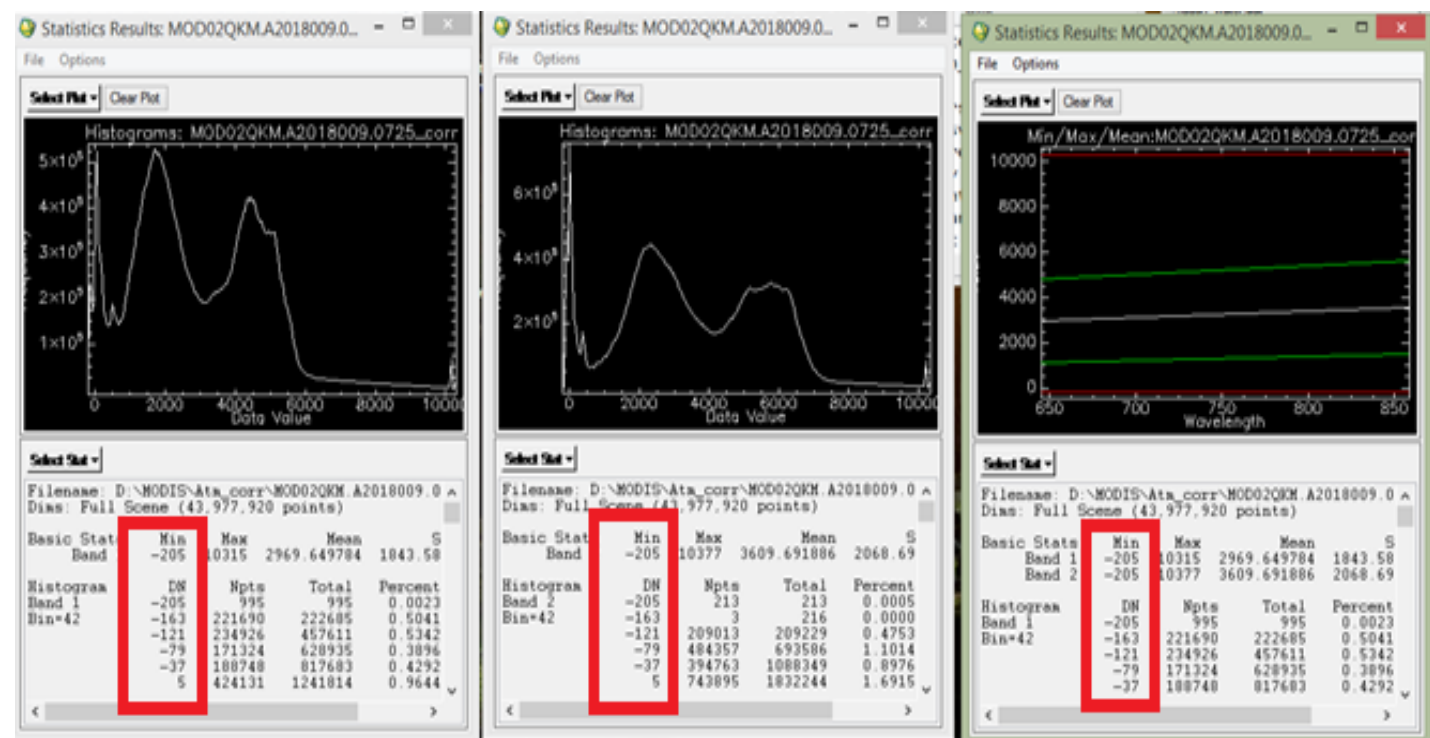

Fig. 4: FLAASH software, it is not unusual to have some negative values (red square) in some pixels of every band. It just means that FLAASH was unable to create an appropriate model for those pixels. They are often areas of very low or very height radiance. We can try and reduce this effect by increasing the visibility amount to $80-100 \mathrm{Km}$ if the scene is very clear.

Rescaling FLAASH results to 0-1 reflectance scale for each band of the steak using band math. Write this formula in band math:

$$
(\text { b1 le } 0)^{*} 0+(\text { b1 ge 10000 })^{*} 1+(\text { b1 gt } 0 \text { and b1 lt 10000 }) * \text { float (b1)/10000 }
$$

After this step we have positive values (red square) in pixels of bands. 


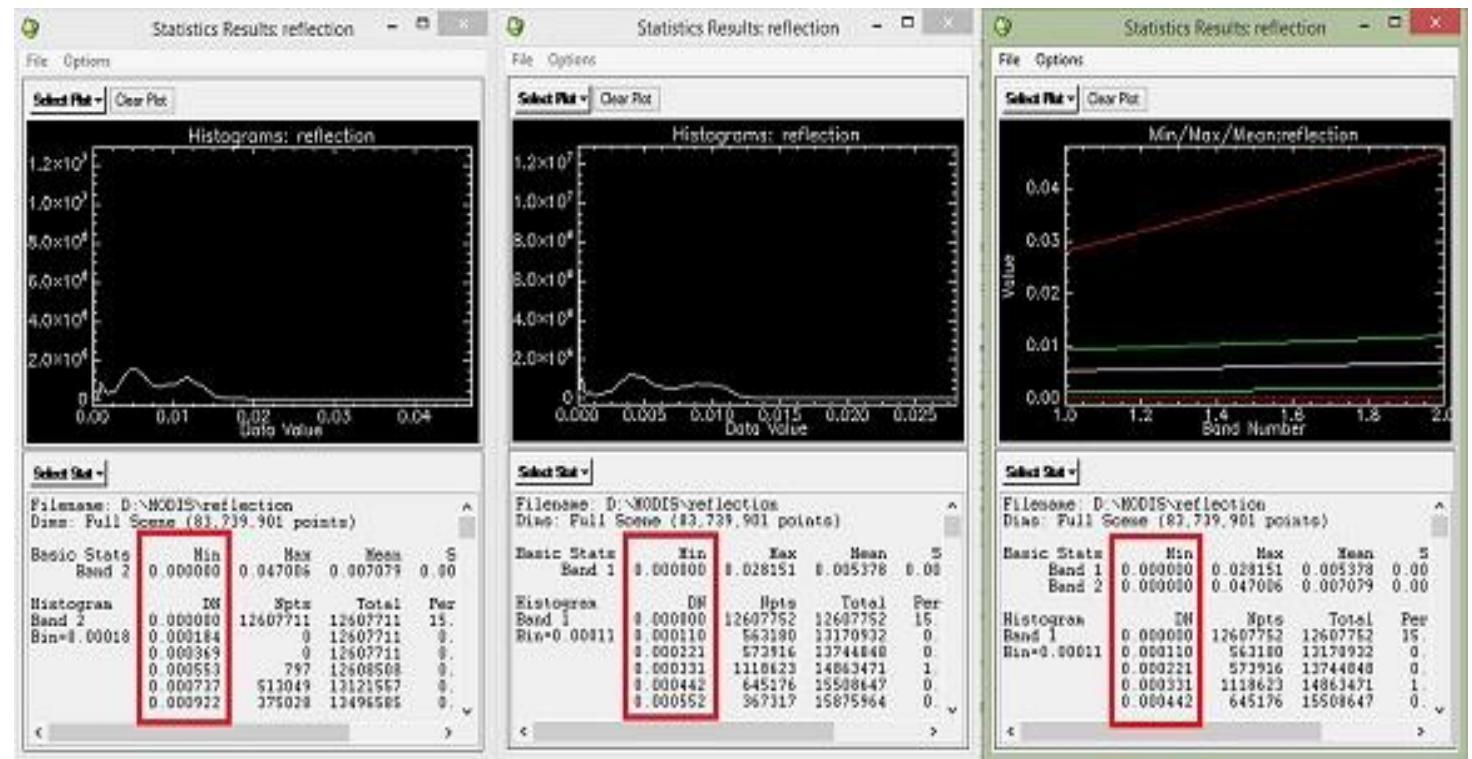

Fig. 5: Rescaling FLAASH results to 0-1 reflectance scale for each band of the steak using band math.

Fast line of sight atmospheric analysis of spectral hyperubes is an atmospheric correction reflection from hyper spectral and multispectral images (Fig 4). The obtained results showed that suspended sediments in the deep sea and ocean waters have important relationships with reflectance spectral. The coastal area in this study containing a large amount of suspended sediment (SS), coloured dissolved organic matter is distinguished from relatively deep sea and ocean waters. Blue line (Fig 5) are located in deep water zone where the reflectance effects from sediment and bottom material were very small. One of the most important factors of the long term sediment is the wind speed on the sea and ocean surface waters. Other important environmental factors that affect the rate of in the two events in Caspian sea and Persian Gulf coastal area are the dust coming for the desert areas the near this zone and the phytoplankton coming up by the wind.

In addition, low depth for these areas is another key factor: the average depth is 35 metres and the deepest parts located along the Iranian coast are about 100 metres for Persian Gulf. In principle, using a combination of simulations, in situ data and spectral data provide by satellite, an estimated of the concentration $\left[\mathrm{g} / \mathrm{l}^{2}\right]$ of sediments in the area of interest can be attempted. In this work just the possibility to detect polluted areas has been shown. Of course, in proximity of the shore (shallow water case) the estimation of the suspended sediment could be contaminated by the signal reflected the sea bottom.

\section{Conclusion}

The results obtained in this study show a strong relationship between concentrations of suspended and multi sensor satellite data. This study reported the analysis obtained by using imagery MODIS-Terra satellite to detect sediments in east coast of Caspian Sea field near the border between Turkmenistan and Iran, and north-western of Persian Gulf between the border Iran, Iraq, Kuwait. Satellite measurements presented to be an essential tool for suspended sediments detection and monitoring. ENVI software and MODIS on NASAs Terra satellite imagery have been used in order to detect suspended sediments.

The suspended sediments close to the coastal area have been successfully detected not only using ENVI software for MODIS-Terra satellite, but also through the use of MODIS-Terra data. A positive linear relationship between the MODISTerra surface reflectance band 1 and in situ turbidity was found in this study. Moreover this study proposes the integration of a developed methodology with other satellite bands.

The next steps will be to use other bands with MODIS satellite for analysing and better understanding sediments trying to discriminate their concentration and apply GIS software for delineate the polluted areas and estimate the sediment size. 


\section{References}

[1] M. Marignani, D. Bruschi, D. Astiaso Garcia, R. Frondoni, E Carli, M. S. Pinna, F. Cumo, F. Gugliermetti, A. Saatkamp, A. Doxa, E.M. Queller, M. Chaieb, M. Bou Dagher-Kharrat, R. El Zein, S El Jeitani, C. Khater, S Mansour, A. AlShami, G. Harik, I. Alameddine, M. El-Fadel, C. Blasi, "Identification and prioritization of areas with high environmental risk in Mediterranean coastal areas: A flexible approach," Sci. Total Environ., vol. 590-591, no. May, pp. 566-578, 2017.

[2] G.Hari, I. Alameddine, R.Maroun, G. Rachid, D. Bruschi, D.A. Garcia, M.El-Fadela, "Implications of adopting a biodiversity-based vulnerability index versus a shoreline environmental sensitivity index on management and policy planning along coastal areas," J. Environ. Manage., vol. 187, pp. 187-200, 2017.

[3] A. Fiduccia, F. Gugliermetti, F. Pagliaro, B. Mattoni, F. Nardecchia, C.Canu, "Web-based spatial decision support systems to monitor and manage coastal environments," IET Conference Publications, 2016(CP704), 2016.

[4] J. G. Acker, S. Ouillon, J. Gould, W. Richard, R. A. Arnone, "Measuring Marine Suspended Sediment Concentrations from Space: History and Potential," Int. Conf. Remote Sens. Mar. Coast. Environ., 2005.

[5] M. Baeye, R. Quinn, S. Deleu, and M. Fettweis, "Detection of shipwrecks in ocean colour satellite imagery," $J$. Archaeol. Sci., vol. 66, pp. 1-6, 2016.

[6] F. Shen, W. Verhoef, Y. Zhou, M. S. Salama, X. Liu, "Satellite Estimates of Wide-Range Suspended Sediment Concentrations in Changjiang (Yangtze) Estuary Using MERIS Data," Estuaries and Coasts, vol. 33, no. 6, pp. 14201429, 2010.

[7] K. Ruddick, Q. Vanhellemont, J. Yan, G. Neukermans, G. Wei, S. Shang, "Variability of suspended particulate matter in the Bohai Sea from the geostationary Ocean Color Imager (GOCI)," Ocean Sci. J., vol. 47, no. 3, pp. 331-345, 2012.

[8] Z. Suif, A. Fleifle, C. Yoshimura, O. Saavedra, "Spatio-temporal patterns of soil erosion and suspended sediment dynamics in the Mekong River Basin," Sci. Total Environ., vol. 568, pp. 933-945, 2016.

[9] K. Toming, T. Kutser, R. Uiboupin, A. Arikas, K. Vahter, B. Paavel, "Mapping water quality parameters with Sentinel3 Ocean and Land Colour Instrument imagery in the Baltic Sea," Remote Sens., vol. 9, no. 10, 2017.

[10] J. D. Shutler, P. E. Land, T. J. Smyth, S. B. Groom, "Extending the MODIS $1 \mathrm{~km}$ ocean colour atmospheric correction to the MODIS $500 \mathrm{~m}$ bands and $500 \mathrm{~m}$ chlorophyll-a estimation towards coastal and estuarine monitoring," Remote Sens. Environ., vol. 107, no. 4, pp. 521-532, 2007.

[11] J. J. Wang and X. X. Lu, "Estimation of suspended sediment concentrations using Terra MODIS: An example from the Lower Yangtze River, China," Sci. Total Environ., vol. 408, no. 5, pp. 1131-1138, 2010.

[12] G. Laneve and R. Luciani, "Developing a satellite optical sensor based automatic system for detecting and monitoring oil spills," in Proceedings of the 2015 IEEE 15th Int. Conf. Environ. Electr. Eng. EEEIC 2015, pp. 1653-1658, 2015.

[13] N. J. Murray, D. A. Keith, L. M. Bland, R, Ferrari, M. B. Lyons, R. Lucas, N. Pettorelli, E. Nicholson, "The role of satellite remote sensing in structured ecosystem risk assessments," Sci. Total Environ., vol. 619-620, pp. 249-257, 2018.

[14] R. M. Holmes, J. W. McClelland, B. J. Peterson, I. A. Shiklomanov, A. I. Shiklomanov, A. V. Zhulidov, V. V. Gordeev, N. N. Bobrovitskaya, "A circumpolar perspective on fluvial sediment flux to the Arctic ocean," Global Biogeochem. Cycles, vol. 16, no. 4, pp. 45-1-45-14, 2002.

[15] J. Bartram and R. Ballance, "Water quality monitoring : a practical guide to the design and implementation of freshwater quality studies and monitoring programs ," World Health Organization \& United Nations Environment Programme [Online].

Available: https://apps.who.int/iris/bitstream/handle/10665/41851/0419217304_eng.pdf?sequence=1\&isAllowed=y

[16] C. Gamvroudis, N. P. Nikolaidis, O. Tzoraki, V. Papadoulakis, N. Karalemas, "Water and sediment transport modeling of a large temporary river basin in Greece," Sci. Total Environ., vol. 508, pp. 354-365, 2015.

[17] J. P. Appleby and D. J. Scarratt, "Physical effects of suspended solids on marine and estuarine fish and shellfish, with special reference to ocean dumping: a literature review," Can. Tech. Rep. Fish. Aquat. Sci., no. 1681, p. 41, 1989. [Online]. Available: http://publications.gc.ca/site/eng/420468/publication.html.

[18] A. C. Ardelean, A. Onaca, P. Urdea, A. Sărășan, "Quantifying postglacial sediment storage and denudation rates in a small alpine catchment of the Făgăraș Mountains (Romania)," Sci. Total Environ., vol. 599-600, pp. 1756-1767, 2017.

[19] Q. Wu, J. Qi, X. Xia, "Long-term variations in sediment heavy metals of a reservoir with changing trophic states: Implications for the impact of climate change," Sci. Total Environ., vol. 609, pp. 242-250, 2017. 
[20] D. Astiaso Garcia, F. Cumo, F. Gugliermetti, and F. Rosa, "Hazardous and noxious substances (HNS) risk assessment along the italian coastline," Chemical Engineering Transactions, vol. 32, pp. 115-120, 2013.

[21] L. De Santoli, F. Cumo, D. Astiaso Garcia, D. Bruschi, "Coastal and marine impact assessment for the development of an oil spill contingency plan: The case study of the east coast of Sicily," WIT Transactions on Ecology and the Environment, vol. 149, pp. 285-296, 2011.

[22] F. Cumo, F. inquepalmi, D. Astiaso Garcia, "Data gathering guidelines for the mapping of environmental sensitivity to oil spill of the Italian coastlines," WIT Transactions on the Built Environment, pp. 119, 2008.

[23] F. Nardecchia, L. Gugliermetti, F. Gugliermetti, "CFD analysis of onshore oil pipelines in permafrost," in Proceedings of AIP Conference, pp. 1863, 2017.

[24] D. Astiaso Garcia, D. Bruschi, F. Cumo, F. Gugliermetti, "The Oil Spill Hazard Index (OSHI) elaboration. An oil spill hazard assessment concerning Italian hydrocarbons maritime traffic," Ocean and Coastal Management, vol. 80, pp. 1$11,2013$.

[25] F. Gugliermetti, F. Cinquepalmi, D. Astiaso Garcia, "The use of environmental sensitivity indices (ESI) maps for the evaluation of oil spill risk in Mediterranean coastlines and coastal waters," WIT Transactions on Ecology and the Environment, vol. 102, pp. 593-600, 2007.

[26] A. Al Shami, G. Harik, I. Alameddine, D. Bruschi, D. Astiaso Garcia, M. El-Fadel, "Risk assessment of oil spills along the Mediterranean coast: A sensitivity analysis of the choice of hazard quantification," Science of the Total Environment, vol. 574, pp. 234-245, 2017.

[27] F. J. Millero and F. Huang, "The density of seawater as a function of salinity (5 to $70 \mathrm{~g} \mathrm{~kg}-1)$ and temperature (273.15 to $363.15 \mathrm{~K})$," Ocean Sci., vol. 5, pp. 91-100, 2009.

[28] M. Marignani, D. Bruschi, D. Astiaso Garcia, R. Frondoni, E. Carli, M.S. Pinna, F. Cumo, F. Gugliermetti, A. Saatkamp, A. Doxa, E.M. Queller, M. Chaieb, M. Bou Dagher-Kharrat, R. El Zein, S. El Jeitani, C. Khater, S. Mansour, A. AlShami, G. Harik, I. Alameddine, M. el-Fadel, and C. Blasi, "Identification and prioritization of areas with high environmental risk in Mediterranean coastal areas: A flexible approach," Science of the Total Environment, vol. 590591, pp. 566-578, 2017.

[29] L. De Santoli, D. Astiaso Garcia, and A.C. Violante, "Planning of flood defence management and rehabilitation of the natural habitat in the downstream part of the river Tiber," WIT Transactions on the Built Environment, 2008, pp. 25.

[30] G. Harik, I. Alameddine, R. Maroun, G. Rachid, D. Bruschi, D. Astiaso Garcia, and M. El-Fadel, "Implications of adopting a biodiversity-based vulnerability index versus a shoreline environmental sensitivity index on management and policy planning along coastal areas," Journal of environmental management, vol. 187, pp. 187-200, 2017.

[31] C. M. Long and T. M. Pavelsky, "Remote sensing of suspended sediment concentration and hydrologic connectivity in a complex wetland environment," Remote Sens. Environ., vol. 129, pp. 197-209, 2013.

[32] R. M. Mobasheri and H. Mousavi. "Remote sensing of suspended sediments in surface waters using MODIS images," Proc. XXth ISPRS Congress, Geo-Imagery Bridging Continent, Istanbul. 2004.

[33] M. J. Moreno-Madrinan, M. Z. Al-Hamdan, D. L. Rickman, F. E. Muller-Karger, "Using the surface reflectance MODIS terra product to estimate turbidity in Tampa Bay, Florida," Remote Sens., vol. 2, no. 12, pp. 2713-2728, 2010.

[34] M. Baeye and M. Fettweis, "In situ observations of suspended particulate matter plumes at an offshore wind farm, southern North Sea," Geo-Marine Lett., vol. 35, no. 4, pp. 247-255, 2015.

[35] V. Rodríguez-guzmán and F. Gilbes-santaella, "Using MODIS $250 \mathrm{~m}$ Imagery to Estimate Total Suspended Sediment in a Tropical Open Bay," Int. J. Syst. Appl. Eng. Dev., vol. 3, no. 1, pp. 36-44, 2009.

[36] M. Fettweis, J. Monbaliu, M. Baeye, B. Nechad, and D. Van den Eynde, "Weather and climate induced spatial variability of surface suspended particulate matter concentration in the North Sea and the English Channel," Methods Oceanogr., vol. 3-4, no. November, pp. 25-39, 2012.

[37] R. J. W. Brewin, S. Sathyendranath, D. Müller, C.Brockmann, P. Y. Deschamps, E. Devred, R. Doerffer, N. Fomferra, B. Franz, M. Grant, S. Groom, A. Horseman, C. Hu, H. Krasemann, Z. Ping Lee, S. Maritorena, F. Mélin, M. Peters, T. Platt, P. Regner, T. Smyth, F. Steinmetz, J. Swinton, J. Werdell, G. N. White, "The Ocean Colour Climate Change Initiative: III. A round-robin comparison on in-water bio-optical algorithms," Remote Sens. Environ., vol. 162, pp. 271294, 2015.

[38] Maritorena, F. Mélin, M. Peters, G. N. White, "The Ocean Colour Climate Change Initiative: III. A round-robin comparison on in-water bio-optical algorithms," Remote Sens. Environ., vol. 162, pp. 271-294, 2015. 
[39] M. Zhang, J. Tang, Q. Dong, Q. T. Song, J. Ding, "Retrieval of total suspended matter concentration in the Yellow and East China Seas from MODIS imagery," Remote Sens. Environ., vol. 114, no. 2, pp. 392-403, 2010.

[40] C. K. Wang and W. D. Philpot, "Using airborne bathymetric lidar to detect bottom type variation in shallow waters," Remote Sens. Environ., vol. 106, no. 1, pp. 123-135, 2007.

[41] M. Saghali, R. Baqraf, and S. A. Hosseini, R. Patimar, "Assignment of Concentration of Heavy Metals ( Cr , Zn , Cd , $\mathrm{Pb}$ ) In Sediments of Gorgan Bay and South East the Caspian Sea ( Golestan Province - Iran )," Environment and Ecology Research, vol. 1, no. 2, pp. 27-31. 2013.

[42] Getting Started with ENVI, pp. 1-234, 2009. [Online]. Available: www.harrisgeospatial.com/portals/0/pdfs/envi/getting_started_with_envi.pdf

[43] Using ENVI and Geographic Information Systems ( GIS ) Whitepaper. [Online]. Available: https://vip.arizona.edu/documents. pp. 303-786-9900

[44] Get the Information You Need from Imagery. [Online]. Available: www.harrisgeospatial.com/portals/0/.../envi_literature_pack.pdf

[45] N. Kazanc1, T. Gulbabazadeh, S. A.G. Leroy, Ö. Ileri, "Sedimentary and environmental characteristics of the GilanMazenderan plain, northern Iran: influence of long- and short-term Caspian water level fluctuations on geomorphology," Journal of Marine Systems, vol. 46, issues 1-4, pp. 145-168. 2004.

[46] S. W. Fowler, "Pollution in the Gulf: Monitoring the marine environment," [Online]. Available: https://www.iaea.org/sites/default/files/35205980913.pdf

[47] B. Bojarczyk, "Geopolitics of the persian gulf region," pp. 80-100, 2012. [Online]. Available: www.pan-ol.lublin.pl

[48] Vermote, E. F., J. C. Roger, and J. P. Ray. "MODIS surface reflectance user's guide collection 6,” NASA Goddard Space Flight Center: Greenbelt, MD, USA, 2015.

[49] M. H. Gholizadeh, A. M. Melesse, L. Reddi, "A Comprehensive Review on Water Quality Parameters Estimation Using Remote Sensing Techniques,” Sensors (Basel). 2016, vol. 16, no. 8, pii: E1298.

[50] Ø. Rudjord and Ø. Due Trier, "Evaluation of FLAASH atmospheric correction," Nor. Regnesentral ,Norwegian Comput. [Online]. Available: https://www.nr.no/directdownload/1338298623/Rudjord-Trier_FLAASH_2012.pdf

[51] S. M. Adler-Golden, L. S. Bernstein, M. W. Matthew, R. L. Sundberg, A. J. Ratkowski, "Atmospheric compensation of extreme off-nadir hyperspectral imagery from Hyperion," Proceedings Volume 6565, Algorithms and Technologies for Multispectral, Hyperspectral, and Ultraspectral Imagery XIII; 65651P (2007).

[52] Y. Guo and F. Zeng, "Atmospheric Correction Comparison of Spot-5 Image Based on Model Flaash and Model Quac," ISPRS - Int. Arch. Photogramm. Remote Sens. Spat. Inf. Sci., 2012, vol. XXXIX-B7, no. September, pp. 7-11. 